\title{
Effects of centralizing acute stroke services
}

\section{A prospective cohort study}

Sidsel Hastrup, MD, Soren P. Johnsen, MD, PhD, Thorkild Terkelsen, MD, Heidi H. Hundborg, Biostatistician, PhD, Paul von Weitzel-Mudersbach, MD, PhD, Claus Z. Simonsen, MD, PhD, Niels Hjort, MD, PhD,

Anette T. Møller, MD, PhD, Thomas Harbo, MD, PhD, Marika S. Poulsen, MD,

Noella Ruiz de Morales Ayudarte, MD, Dorte Damgaard, MD, PhD, and Grethe Andersen, MD, DMSci

Neurology ${ }^{\circledR}$ 2018;91:e236-e248. doi:10.1212/WNL.0000000000005822

\section{Abstract \\ Objective}

To investigate the effects of centralizing the acute stroke services in the Central Denmark Region (CDR).

\section{Methods}

The CDR (1.3 million inhabitants) centralized acute stroke care from 6 to 2 designated acute stroke units with 7-day outpatient clinics. We performed a prospective "before-and-after" cohort study comparing all strokes from the CDR with strokes in the rest of Denmark to discover underlying general trends, adopting a difference-in-differences approach. The population comprised 22,141 stroke cases hospitalized from May 2011 to April 2012 and May 2013 to April 2014.

\section{Results}

Centralization was associated with a significant reduction in length of acute hospital stay from a median of 5 to 2 days with a length-of-stay ratio of 0.53 (95\% confidence interval $0.38-0.75$, data adjusted) with no corresponding change seen in the rest of Denmark. Similarly, centralization led to a significant increase in strokes with same-day admission (mainly outpatients), whereas this remained unchanged in the rest of Denmark. We observed a significant improvement in quality of care captured in 11 process performance measures in both the CDR and the rest of Denmark. Centralization was associated with a nonsignificant increase in thrombolysis rate. We observed a slight increase in readmissions at day 30, but this was not significantly different from the general trend. Mortality at days 30 and 365 remained unchanged, as in the rest of Denmark.

\section{Conclusions}

Centralizing acute stroke care in the CDR significantly reduced the length of acute hospital stay without compromising quality. Readmissions and mortality stayed comparable to the rest of Denmark.

\author{
Correspondence \\ Dr. Hastrup \\ sidshast@rm.dk
}




\section{Glossary}

CDR = Central Denmark Region; DID = difference-in-differences; DSR = Danish Stroke Registry; HR = hazard ratio.

Stroke is one of the costliest health care conditions globally. ${ }^{1,2}$ In already overstretched health care budgets, efficient organization of stroke services is therefore essential to ensure high quality of care and the best possible outcomes for patients.

Organized stroke care provided by specialized multidisciplinary teams is associated with better quality and lesser risk of death and dependency. ${ }^{3-6}$ Furthermore, a higher patient volume at stroke units has been associated with improved quality of early stroke care, reduced length of stay, lower mortality, and reduced hospitalization costs. ${ }^{7-10}$ However, only a few studies have examined the effects of centralizing stroke care to fewer designated stroke units. ${ }^{11,12}$ Moreover, these studies may have been influenced by methodological limitations because they were conducted in selected urban populations without adjustment of clinical outcomes for stroke severity at stroke onset, ${ }^{2,13}$ and information on important aspects such as the use of acute reperfusion therapy rates $^{14-17}$ and hospital readmissions has been missing. ${ }^{18,19}$ Increased funding may also have confounded the effects of centralization per se. ${ }^{20}$

The Central Denmark Region (CDR) implemented specialization and centralization of the acute stroke services in 2012 to ensure that all stroke patients would receive care in designated high-volume acute stroke units and to reduce overall costs. ${ }^{21}$ We investigated the effects of this reorganization.

\section{Methods}

\section{System change}

The acute stroke services reorganization in the CDR $(\approx 1.3$ million inhabitants in an area of 5,040 sq miles) implied that all acute stroke care was to be provided at only 2 designated acute stroke units in the CDR offering revascularization therapy (thrombolysis at both; endovascular therapy in 1 unit). Four other local hospitals with stroke units had provided acute stroke care before the reorganization, and patients would be admitted to the local hospital provided that they resided in its catchment area and were not candidates for acute revascularization therapy. For acute revascularization candidates, the reorganization meant no change. Three of the closed stroke units were "nonspecialized units" supervised by specialists in internal medicine. The reorganization reduced the total number of acute stroke beds in the CDR from 54 to $26{ }^{21}$ To meet treatment demand with only 2 dedicated stroke centers in the CDR, the centers established outpatient clinic for patients with suspected minor stroke (self-dependent although with neurologic symptoms) and TIA. The outpatient clinics were open 7 days a week during the daytime and staffed by an experienced neurovascular team. Patients needing in-hospital rehabilitation after the acute care could be transferred to a rehabilitation hospital unit or a local hospital $7 \mathrm{~d} /$ wk. The reorganization also implied setting up earlydischarge home team care to improve patients' transition to stroke care in the community setting.

Centralization of the prehospital stroke code activation was part of the reorganization. In all suspected acute stroke cases, the general practitioner or prehospital service phoned an experienced neurologist who was available $24 \mathrm{~h} / \mathrm{d}$ from either of the 2 high-volume acute stroke units. The stroke code was defined as acute focal neurologic deficits with no other obvious reasons than a possible cerebrovascular event. Regardless of whether patients were candidates for acute revascularization therapy, they were admitted directly to one of these units.

\section{Outcomes}

We investigated the effect of the reorganization from length of acute and total hospital stay, all-cause bed days, quality of and delays in acute stroke care, hospital readmissions, and mortality.

Admission length was counted as half rather than whole days when a patient died or was discharged from hospital on the day of admission. To ensure that the total length of the hospital stay included rehabilitation regardless of local organizational differences, admissions on the day after discharge were compiled in the total stay.

Nonacute hospital stay (total hospital stay - acute hospital stay) was defined as the total length of hospital stay spent in nonacute stroke care settings, including rehabilitation.

All-cause bed days were defined as the total number of days spent in hospital within the first year, including the total hospital stay of the initial stroke admission. To ensure that outpatient visits were not counted as part of all-cause bed days, only new admissions (acute/nonacute) $\geq 24$ hours were included.

To be considered a readmission, at least 1 day was required between the day of discharge and the next admission date. Only acute admissions $\geq 24$ hours were included. All admissions due to carotid artery surgery were excluded because they were considered part of the planned stroke care.

We evaluated quality of care using 11 clinical guidelinerecommended process performance measures of acute stroke care (table 1). We defined "all-or-none" of the 11 measures as the proportion of stroke events involving all eligible measures for the individual patient. We evaluated the quality of the hyperacute phase from the ratio of all ischemic stroke events 
Table 1 Definition of the process performance measures

Process performances measures

Specialized stroke unit $\leq 2 \mathrm{~d}$

Proportion of patients with acute stroke who are admitted to a stroke unit within the second day of admission.

Antiplatelet therapy $\leq 2 \mathrm{~d}$

Proportion of patients with acute ischemic stroke without atrial fibrillation who receive platelet inhibitor therapy within the second day of admission.

Brain imaging (CT or MRI) $\leq 0 \mathrm{~d}$

Proportion of patients with acute stroke who receive CT/MR scan on the day of admission.

Physiotherapy (assessment) $\leq 2 \mathrm{~d}$

Proportion of patients with acute stroke who are assessed by a physiotherapist regarding the need for rehabilitation (including type and extent) within the second day of admission.

Occupational therapist (assessment) $\leq 2 \mathrm{~d}$

Proportion of patients with acute stroke who are assessed by an occupational therapist regarding the need for rehabilitation (including type and extent) within the second day of admission.

Mobilization $\leq 0 \mathrm{~d}$

Proportion of patients with acute stroke who are mobilized on the day of admission.

Nutrition (assessment) $\leq 2 \mathrm{~d}$

Proportion of patients with acute stroke who receive a nutritional risk assessment within the second day of admission.

Indirect swallow test $\leq 2 \mathrm{~d}$

Proportion of patients with acute stroke who are assessed by a swallowing test (indirect) on the day of admission before receiving food or fluids to assess swallowing function and risk of aspiration.

Direct swallow test $\leq 2 \mathrm{~d}$

Proportion of patients with acute stroke who are assessed by a swallowing test (direct) on the day of admission before receiving food or fluids to assess swallowing function and risk of aspiration.

Imaging of the carotids $\leq 4 \mathrm{~d}$

Proportion of patients with acute ischemic stroke who are examined with ultrasound CT/MR angiography of the carotid arteries within the fourth day of admission.

Anticoagulation therapy $\leq 14 \mathrm{~d}$

Proportion of patients with ischemic stroke and atrial fibrillation who receive oral anticoagulation therapy within $14 \mathrm{~d}$ after admission.

Abbreviation: $\mathrm{MR}=$ magnetic resonance.

that received thrombolysis and the proportion of thrombolysed patients with a door-to-needle time $<60$ minutes. To evaluate hospital admission delay, we estimated the proportion of patients admitted within 4.5 hours from symptom onset.

\section{Study design}

We conducted a prospective before-and-after cohort study using the rest of Denmark ( $\approx 4.3$ million inhabitants) to compare for underlying general trends in stroke care and patient outcomes in a difference-in-differences (DID) approach. The "before" period was defined as the 12 months leading up to the reorganization (May 1, 2011-April 30, 2012), and the "after" period was defined as the 12-month period starting 1 year after initiation of the reorganization at which time the transition was considered to have been fully implemented (May 1, 2013-April 30, 2014).
We used the Danish Stroke Registry (DSR) ${ }^{22}$ to identify all stroke events. Reporting to the DSR is mandatory for all acute strokes (patients $\geq 18$ years of age) at the hospital level. Given the Danish tradition of admitting almost all patients with acute stroke symptoms to hospital, virtually all acute stroke patients in Denmark are registered. ${ }^{23}$ The completeness of stroke event registration in the DSR exceeds $90 \%$, and studies show that the DSR has a high validity. ${ }^{24}$ The DSR also provided information on baseline patient characteristics, length of acute hospital stay, and outcomes.

The Danish National Patient Register ${ }^{25}$ provided information on subsequent hospitalizations, including transfers from the acute stroke unit to in-hospital rehabilitation and readmissions. 
The Danish Civil Registration System provided information on patients' vital status. ${ }^{26}$

We restricted the population to individuals with stroke events with reliable data on length of acute hospital stay and a known vital status in the Danish Civil Registration System (figure).

\section{Statistical analysis}

We compared outcomes from before and after the reorganization using regression methods based on the DID. The DID between the CDR and the rest of Denmark was estimated as an interaction term between period (before vs after) and region (CDR vs rest of Denmark).

The study was event based; i.e., individual patients could be included with several stroke episodes. Using multivariable models, we adjusted for age, sex, living arrangement, previous stroke, diabetes mellitus, atrial fibrillation, hypertension, smoking habits, alcohol use, stroke severity (Scandinavian Stroke Scale), and subtype of stroke. Missing information was encoded by an indicator variable and included in the analyses, except for patients with missing information on stroke severity, who were excluded from the multivariable models (missing information on stroke severity: 1,058 of 22,141 [4.8\%]). Confidence intervals were based on robust standard errors adjusted for clustering within individual stroke units.

We determined the medians with interquartile range of the length of acute hospital stay, total hospital stay, and all-cause hospital bed day use within the first year. The data were severely right-skewed. We used a generalized linear model

Figure Flowchart of the study population

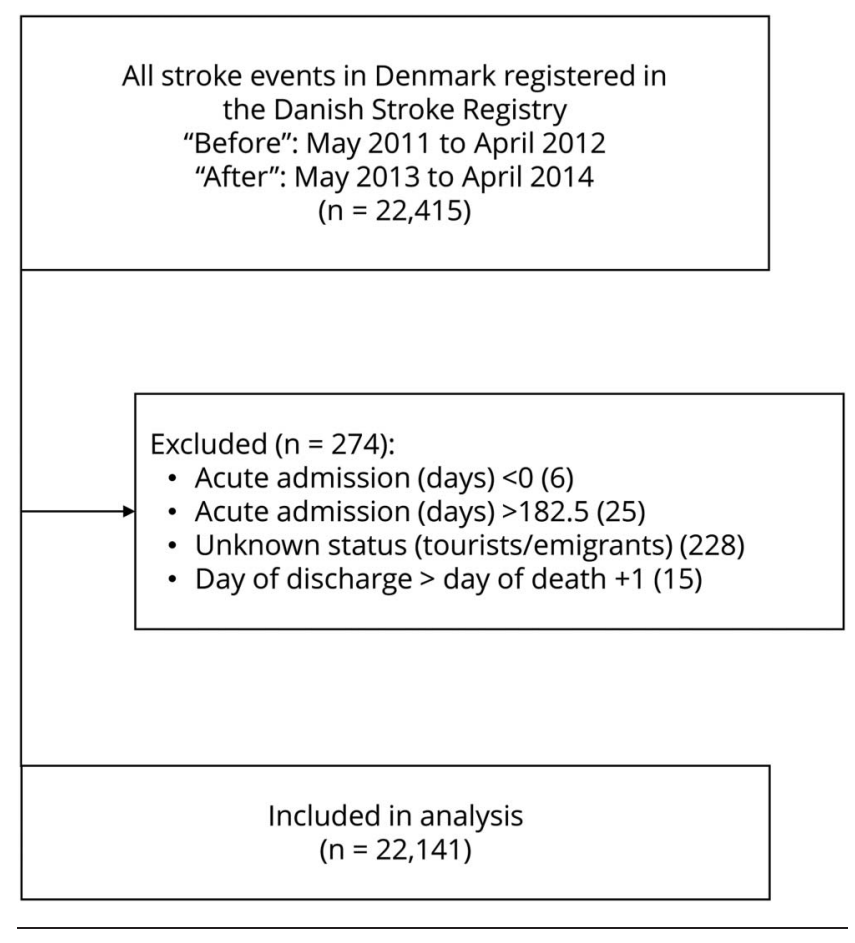

with a log-link and gamma distribution family to compare the length of stay ratios.

For readmissions, we compared hazard ratios (HRs) using multivariable Cox regression encountering the time of a potential readmission or death and analyzed mortality outcomes accordingly. We also calculated adjusted and unadjusted HRs.

For the clinical guidelines-recommended process performance measure, the time of admission and the rates and timing of thrombolysis were analyzed using binomial regression. Unadjusted risk ratios were calculated. We included only cases in which the health professionals caring for the individual patient had found the specific process measure to be relevant.

We used the Stata 13.0 package (StataCorp LP, College Station, TX) for all analyses.

\section{Standard protocol approvals, registrations, and patient consents}

The study was approved by the Danish Data Protection Agency (No. 1-16-02-213-15) and the Danish Clinical Registries. Under Danish law, registry-based studies require no ethics approval or patient consent.

According to Danish law, it is not possible to provide public access to the dataset, which is based on linkage of data from nationwide public registries. Access to Danish registry data can only be granted to individual researchers on seeking approval from the National Agency for Data Protection. It is therefore not possible to place the dataset in a public repository.

\section{Results}

After the exclusion of $1.2 \%$ of the identified stroke events, 22,141 cases remained in the study (figure). A total of 4,645 (21\%) of all stroke events in Denmark occurred in the CDR during the study period. Of these, nonspecialized stroke units managed 603 (26\%) events in the CDR before the reorganization.

Baseline characteristics of the CDR patients compared with those recorded for the rest of Denmark in the before and after periods are shown in table 2 . There were no substantial differences between the groups' baseline characteristics.

The study period saw a significant risk-adjusted reduction in the length of the acute hospital stay from a median of 5 to 2 days in the CDR (table 3 ). We saw no similar change in the rest of Denmark, for which the median acute hospital stay remained 5 days. Similarly, we observed a significant increase in the proportion of stroke events with a length of stay $<24$ hours (the majority being outpatients) in the CDR from $1.4 \%$ to $6.8 \%$. In the rest of Denmark, this proportion increased only from $1.1 \%$ to $1.6 \%$. The length of total stay, including 
Table 2 Characteristics of patients before and after centralization of acute stroke services in the CDR compared with the rest of Denmark

\begin{tabular}{|c|c|c|c|c|}
\hline & \multicolumn{2}{|l|}{ CDR } & \multicolumn{2}{|c|}{ Rest of Denmark } \\
\hline & Before & After & Before & After \\
\hline Stroke cases, $\mathbf{n}$ & 2,290 & 2,355 & 8,802 & 8,694 \\
\hline \multicolumn{5}{|l|}{ Stroke incidence } \\
\hline Stroke cases $/ 100,000>18 \mathrm{y}$ of age & 234.2 & 237.0 & 260.6 & 253.8 \\
\hline \multicolumn{5}{|l|}{ Unit type, n (\%) } \\
\hline Nonacute unit (without thrombolysis) & $909(40)$ & $9(0)$ & - & - \\
\hline Nonspecialized unit & $603(26)$ & $0(0)$ & - & - \\
\hline Age, mean (SD), y & $72(14)$ & $71(13)$ & $72(13)$ & $72(13)$ \\
\hline Female sex, $\mathrm{n}(\%)$ & $1,038(45)$ & $1,046(44)$ & $4,135(47)$ & $4,014(46)$ \\
\hline \multicolumn{5}{|l|}{ Stroke severity } \\
\hline SSS score, median (IQR) & $48(25)$ & $48(21)$ & $50(21)$ & $50(20)$ \\
\hline Unknown, n (\%) & $116(5)$ & $46(2)$ & $588(7)$ & $308(4)$ \\
\hline \multicolumn{5}{|l|}{ Stroke type, ${ }^{b}$ n (\%) } \\
\hline Intracerebral hemorrhage & $315(13)$ & $283(12)$ & $897(10)$ & $1,021(12)$ \\
\hline Ischemic stroke & $1,822(80)$ & $2,063(87)$ & $7,492(85)$ & $7,345(84)$ \\
\hline Not specified & $153(7)$ & $9(0)$ & $413(5)$ & $328(4)$ \\
\hline \multicolumn{5}{|l|}{ Former stroke, n (\%) } \\
\hline Former stroke & $513(22)$ & $524(22)$ & $2,198(25)$ & $2,134(25)$ \\
\hline No former stroke & $1,740(76)$ & $1,805(77)$ & $6,411(73)$ & $6,382(73)$ \\
\hline Unknown & $37(2)$ & $26(1)$ & $193(2)$ & $178(2)$ \\
\hline \multicolumn{5}{|l|}{ Hypertension, n (\%) } \\
\hline Hypertension & $1,341(59)$ & $1,421(60)$ & $4,880(55)$ & $4,662(54)$ \\
\hline No hypertension & 903 (39) & $899(38)$ & $3,695(42)$ & $3,840(45)$ \\
\hline Unknown & $46(2)$ & $35(1)$ & $227(3)$ & $192(2)$ \\
\hline \multicolumn{5}{|l|}{ Diabetes mellitus, n (\%) } \\
\hline Diabetes mellitus & $345(15)$ & $364(15)$ & $1,271(14)$ & $1,229(14)$ \\
\hline No diabetes mellitus & $1,890(83)$ & $1,972(84)$ & $7,378(84)$ & $7,345(84)$ \\
\hline Unknown & $55(2)$ & $19(1)$ & $153(2)$ & $120(1)$ \\
\hline \multicolumn{5}{|l|}{ Atrial fibrillation, n (\%) } \\
\hline Atrial fibrillation & $485(21)$ & $473(20)$ & $1,650(19)$ & $1,665(19)$ \\
\hline No atrial fibrillation & $1,759(77)$ & $1,862(79)$ & $6,953(79)$ & $6,867(79)$ \\
\hline Unknown & $46(2)$ & $20(1)$ & $199(2)$ & $162(2)$ \\
\hline \multicolumn{5}{|l|}{ Alcohol use, n (\%) } \\
\hline$\leq 14(F) / 21(M)$ units per week & $1,862(81)$ & $1,956(83)$ & $7,041(80)$ & $6,726(77)$ \\
\hline$>14(F) / 21(M)$ units per week & $192(8)$ & $230(10)$ & $773(9)$ & $1,003(12)$ \\
\hline Unknown & $236(10)$ & $169(7)$ & $988(11)$ & $965(11)$ \\
\hline
\end{tabular}

Smoking, n (\%) 
Table 2 Characteristics of patients before and after centralization of acute stroke services in the CDR compared with the rest of Denmark (continued)

\begin{tabular}{|c|c|c|c|c|}
\hline & \multicolumn{2}{|l|}{ CDR } & \multicolumn{2}{|c|}{ Rest of Denmark } \\
\hline & Before & After & Before & After \\
\hline Daily & $666(29)$ & $695(30)$ & $2,588(29)$ & $2,438(28)$ \\
\hline Former & $677(30)$ & $702(30)$ & $2,117(24)$ & $2,218(26)$ \\
\hline Never & $670(29)$ & $753(32)$ & $2,763(31)$ & $2,738(31)$ \\
\hline Unknown & $277(12)$ & $205(9)$ & $1,334(15)$ & $1,300(15)$ \\
\hline \multicolumn{5}{|l|}{ Living arrangements, n (\%) } \\
\hline Living with someone & $1,278(56)$ & $1,267(54)$ & $4,597(52)$ & $4,575(53)$ \\
\hline Living alone & $945(41)$ & $1,004(43)$ & $3,697(42)$ & $3,594(41)$ \\
\hline Other form of living arrangement & $50(2)$ & $66(3)$ & $320(4)$ & $352(4)$ \\
\hline Unknown & $17(1)$ & $18(1)$ & $188(2)$ & $173(2)$ \\
\hline
\end{tabular}

Abbreviations: $\mathrm{CDR}=$ Central Denmark Region; IQR = interquartile range; SSS = Scandinavian Stroke Score.

${ }^{a}$ Nonspecialized units: Silkeborg, Randers, and Horsens (stroke units with medical doctors specialized in internal medicine; no thrombolysis treatment). Specialized units: Viborg, Holstebro, and Aarhus (highly specialized stroke units with medical doctors specialized in vascular neurology; treatment with thrombolysis was not offered in Viborg, where the department was closed after the reorganization).

${ }^{\mathrm{b}}$ International Classification of Diseases, 10th revision codes: 163, infarction; 161, hemorrhage; and 164, unspecified.

rehabilitation and all-cause bed days, remained unchanged in the CDR and the rest of Denmark. The length of the total nonacute hospital stay, including rehabilitation, increased significantly in CDR but was unchanged in the rest of Denmark (table 3).

All-or-none of 11 process performance measures increased from $50.6 \%$ to $62.3 \%$ in the $\mathrm{CDR}$, reflecting the proportion of stroke events for which all relevant process performance measures of acute stroke care were met. This corresponds to a similar increase from $48.5 \%$ to $60.0 \%$ in the rest of Denmark (table 4). Table 5 shows information on the included process performance measures.

After the reorganization, the proportion of strokes admitted within 4.5 hours from stroke onset increased to $45.4 \%$ in the CDR and $41.1 \%$ in the rest of Denmark. The improvement in time delays for acute stroke service was comparable during this period (table 4).

Of all ischemic strokes, the rates of stroke cases receiving thrombolysis did not change significantly from $14.9 \%$ to $17.8 \%$ in the CDR in the study period, but we saw a significant increase from $9.0 \%$ to $14.1 \%$ in the rest of Denmark. Still, progress in the CDR and in the rest of Denmark did not differ significantly. The proportion of patients receiving thrombolysis within 1 hour of arrival rose significantly in the study period to $\approx 84 \%$ in both the CDR and in the rest of Denmark (table 4).

Readmissions within the first 30 days after discharge occurred in $10.2 \%$ in the "after" period of all strokes. Readmission risk increased significantly in the CDR, but this development was not significantly different from the trend seen in the rest of Denmark. Risk-adjusted readmissions on day 31 to 365 after discharge were unchanged in both CDR and the rest of Denmark (table 6).

Mortality within 30 days after the reorganization dropped to $8.2 \%$ of all strokes and to $18.9 \%$ after 365 days. After risk adjustment, the HRs comparing before to after in the CDR showed no significant differences in mortality rates. The mortality rates in the rest of Denmark also remained unchanged.

The main analyses (length of the acute hospital stay, all-ornone of 11 process performance measures, and mortality within 30 days) were repeated after 1 other region in Denmark that was in the process of centralization was excluded from the control group. This sensitivity analysis did not change the results (data not shown).

\section{Discussion}

Centralization and specialization of the acute stroke services in CDR was associated with a significantly reduced length of the acute hospital stay from 5 to 2 days and more strokes patients handled via the same-day outpatient clinic, whereas the length of acute stay remained unchanged in the rest of Denmark in the study period. The dramatic reduction in the length of acute hospital stay was accompanied by a significant improvement in quality of care, an improvement that followed a trend seen in the rest of Denmark in the study period. 
Table 3 Differences in length of acute and total hospital stay, all-cause bed days, and same-day admissions in the CDR compared with the rest of Denmark after centralization of acute stroke services

\begin{tabular}{|c|c|c|c|c|c|c|c|}
\hline \multirow{3}{*}{$\begin{array}{l}\text { Bed days (in hospital), } \\
\text { median (IQR) }\end{array}$} & \multicolumn{2}{|l|}{ CDR } & \multirow[b]{3}{*}{$\operatorname{LOSR}(95 \% \mathrm{CI})$} & \multicolumn{2}{|c|}{ Rest of Denmark } & \multirow[b]{3}{*}{ LOSR $(95 \% \mathrm{CI})$} & \multirow{3}{*}{$\frac{\text { CDR/Rest of Denmark }}{\text { Before/After }}$} \\
\hline & \multirow[t]{2}{*}{ Before } & \multirow[t]{2}{*}{ After } & & \multirow[t]{2}{*}{ Before } & \multirow[t]{2}{*}{ After } & & \\
\hline & & & & & & & \\
\hline \multicolumn{8}{|l|}{ Acute hospital stay } \\
\hline Unadjusted & $5.00(7)$ & $2.00(3)$ & $0.55(0.38-0.79)$ & $5.00(9)$ & $5.00(8)$ & $0.93(0.79-1.09)$ & $0.59(0.40-0.87)$ \\
\hline Adjusted $^{a}$ & & & $0.53(0.38-0.75)$ & & & $0.94(0.80-1.10)$ & $0.57(0.40-0.82)$ \\
\hline \multicolumn{8}{|l|}{ Total hospital stay } \\
\hline Unadjusted & $7.00(15)$ & $6.00(17)$ & $1.00(0.75-1.32)$ & $7.00(17)$ & $6.00(14)$ & $0.92(0.85-1.00)$ & $1.08(0.81-1.43)$ \\
\hline Adjusted $^{a}$ & & & $0.97(0.86-1.09)$ & & & $0.93(0.87-1.00)$ & $1.06(0.92-1.23)$ \\
\hline \multicolumn{8}{|l|}{ Nonacute hospital stay } \\
\hline Unadjusted & $0(8)$ & $2(14)$ & $1.30(0.87-1.95)$ & $0(0)$ & $0(0)$ & $0.91(0.73-1.13)$ & $1.43(0.92-2.23)$ \\
\hline Adjusted $^{\mathrm{a}}$ & & & $1.36(1.05-1.76)$ & & & $0.92(0.70-1.23)$ & $1.51(1.02-2.25)$ \\
\hline \multicolumn{8}{|l|}{$\begin{array}{l}\text { All-cause hospital bed } \\
\text { days within } 1 \mathrm{y}\end{array}$} \\
\hline Unadjusted & $10.00(22)$ & $9.50(24)$ & $0.99(0.78-1.26)$ & $11.00(24)$ & $9.00(21)$ & $0.94(0.88-1.00)$ & $1.05(0.83-1.33)$ \\
\hline \multirow[t]{2}{*}{ Adjusted $^{a}$} & & & $0.97(0.86-1.09)$ & & & $0.95(0.90-1.01)$ & $1.04(0.90-1.19)$ \\
\hline & \multicolumn{2}{|l|}{ CDR } & & \multicolumn{2}{|c|}{ Rest of Denmark } & & CDR/Rest of Denmark \\
\hline & Before & After & & Before & After & & Before/After \\
\hline$\%(95 \% \mathrm{Cl})$, cases/total & & & $\mathrm{RR}(95 \% \mathrm{Cl})$ & & & RR $(95 \% \mathrm{Cl})$ & DID RR $(95 \% \mathrm{Cl})$ \\
\hline \multicolumn{8}{|l|}{$\begin{array}{l}\text { Acute hospital } \\
\text { stay }<24 \mathrm{~h}\end{array}$} \\
\hline Unadjusted & $\begin{array}{l}1.4(1.0-1.9) \\
33 / 2,290\end{array}$ & $\begin{array}{l}6.8(5.8-7.8) \\
160 / 2,355\end{array}$ & $4.71(2.84-7.82)$ & $\begin{array}{l}1.1(0.9-1.3) \\
99 / 8,802\end{array}$ & $\begin{array}{l}1.6(1.3-1.8) \\
135 / 8,694\end{array}$ & $1.38(0.97-1.96)$ & $3.41(1.88-6.20)$ \\
\hline Adjusted $^{a}$ & & & $5.65(3.35-9.52)$ & & & $1.35(0.93-1.96)$ & $3.89(2.12-7.15)$ \\
\hline
\end{tabular}

Abbreviations: CDR = Central Denmark Region; Cl = confidence interval; DID = difference-in-differences; IQR = interquartile range; LOSR = length of stay ratio; $\mathrm{RR}=$ risk ratio

${ }^{a}$ Adjusted for age, sex, living arrangements, previous strokes, diabetes mellitus, atrial fibrillation, smoking, alcohol, stroke severity, hypertension, and type of stroke.

The reorganized stroke service could have caused potential risks of less use of acute revascularization as travel distances to stroke units became longer, but we recorded a nonsignificant increase in early stroke admissions within 4.5 hours and a nonsignificant increase in the rate of thrombolysis treatment. Furthermore, we found no indication of safety problems in that the 30-day readmission rates in the CDR rose only slightly, not significantly different from the general trend, with mortality remaining unchanged compared to controls from the rest of Denmark.

We used population-based national data on all stroke events registered in the DSR, which enjoys a high level of completeness and validity. The incidence of stroke cases included matched general estimates of stroke incidences ${ }^{27-30}$ in the CDR and the rest of Denmark, which allowed us to control for general trends in stroke care in Denmark. Findings from the
CDR are generalizable to the rest of Denmark because the 5 Danish regions are sociodemographically and health-wise fairly homogeneous. ${ }^{31}$ Detailed registry information on stroke characteristics and outcomes allowed us to study the reorganization extensively by including endpoints not analyzed in previous studies of urban area centralization (England). The present study therefore extends the findings of these British studies. ${ }^{3,11,12}$

We analyzed all hospital readmissions within the entire country during the first year post stroke. This is an essential measure of quality and safety of care, ${ }^{2,18}$ although there is some controversy as to how readmissions should be interpreted. ${ }^{19}$ Unfortunately, the data did not allow us to calculate a reliable rate of recurrent stroke because such registration in the DSR is not mandatory in the early phase after a stroke event, when the risk is highest. 
Table 4 Differences in quality of acute stroke care, hospital admissions within 4.5 hours, and use and timing of intravenous thrombolysis in the CDR compared with the rest of Denmark after centralization of acute stroke services

\begin{tabular}{|c|c|c|c|c|c|c|c|}
\hline & \multicolumn{2}{|l|}{ CDR } & \multirow[b]{3}{*}{ RR $(95 \% \mathrm{Cl})$} & \multicolumn{2}{|l|}{ Rest of Denmark } & \multirow[b]{3}{*}{ RR $(95 \% \mathrm{Cl})$} & \multirow{3}{*}{$\begin{array}{l}\text { CDR/Rest of } \\
\text { Denmark } \\
\text { Before/After } \\
\text { DID RR }(95 \% \mathrm{CI})\end{array}$} \\
\hline & \multirow[t]{2}{*}{ Before } & \multirow[t]{2}{*}{ After } & & \multirow[t]{2}{*}{ Before } & \multirow[t]{2}{*}{ After } & & \\
\hline & & & & & & & \\
\hline \multicolumn{8}{|c|}{$\begin{array}{l}\text { Performance measures, } \\
\%(95 \% \mathrm{Cl}) \text {, cases } / \text { total }^{\mathrm{a}}\end{array}$} \\
\hline \multicolumn{8}{|l|}{ All-or-none ${ }^{b}$} \\
\hline Unadjusted & $\begin{array}{l}50.6(48.5-52.6) \\
1,135 / 2,244\end{array}$ & $\begin{array}{l}62.3(60.3-64.3) \\
1,435 / 2,303\end{array}$ & $1.23(1.01-1.51)$ & $\begin{array}{l}48.5(47.5-49.6) \\
4,121 / 8,490\end{array}$ & $\begin{array}{l}60.0(58.9-61.0) \\
5,043 / 8,409\end{array}$ & $1.24(1.11-1.38)$ & $1.00(0.80-1.24)$ \\
\hline \multicolumn{8}{|c|}{$\begin{array}{l}\text { Acute treatment } \\
\%(95 \% \mathrm{Cl}) \text {, cases/total }\end{array}$} \\
\hline \multicolumn{8}{|c|}{$\begin{array}{c}\text { Admission } \leq 4.5 \mathrm{~h} \\
\text { of all strokes }\end{array}$} \\
\hline Unadjusted & $\begin{array}{l}33.7(31.7-35.6) \\
771 / 2,290\end{array}$ & $\begin{array}{l}45.4(43.3-47.4) \\
1,068 / 2,355\end{array}$ & $1.35(0.86-2.12)$ & $\begin{array}{l}27.9(27.0-28.8) \\
2,455 / 8,802\end{array}$ & $\begin{array}{l}41.1(40.1-42.1) \\
3,573 / 8,694\end{array}$ & $1.47(1.32-1.65)$ & $0.91(0.59-1.43)$ \\
\hline \multicolumn{8}{|l|}{$\begin{array}{l}\text { Thrombolysis } \\
\text { within } 1 \mathrm{~h}\end{array}$} \\
\hline Unadjusted & $\begin{array}{l}64.4(58.8-69.9) \\
186 / 289\end{array}$ & $\begin{array}{l}84.2(80.5-88.0) \\
309 / 367\end{array}$ & $1.31(1.19-1.43)$ & $\begin{array}{l}65.0(61.5-68.5) \\
459 / 706\end{array}$ & $\begin{array}{l}83.9(81.7-86.2) \\
888 / 1,058\end{array}$ & $1.29(1.18-1.41)$ & $1.01(0.90-1.14)$ \\
\hline \multicolumn{8}{|c|}{$\begin{array}{l}\text { Thrombolysis of all } \\
\text { ischemic strokes }^{c}\end{array}$} \\
\hline Unadjusted & $\begin{array}{l}14.9(13.3-16.5) \\
294 / 1,975\end{array}$ & $\begin{array}{l}17.8(16.2-19.5) \\
369 / 2,072\end{array}$ & $1.20(0.55-2.58)$ & $\begin{array}{l}9.0(8.4-9.7) \\
715 / 7,905\end{array}$ & $\begin{array}{l}14.1(13.3-14.9) \\
1,081 / 7,673\end{array}$ & $1.56(1.27-1.91)$ & $0.77(0.36-1.65)$ \\
\hline
\end{tabular}

Abbreviations: $C D R=$ Central Denmark Region; $C I$ = confidence interval; $D I D=$ difference-in-differences; $R R=$ risk ratio.

${ }^{a}$ Cases with the performance measure fulfilled within the defined time of the total cases found relevant for the performance measure.

${ }^{b}$ All-or-none of 11 process performance measures within a defined time period.

c Ischemic strokes includes stroke type not specified.

We evaluated mortality both in the early phase and after 1 year, and we adjusted the risk-adjusted mortality rates for important potential confounders, including stroke severity, a factor not included in mortality rate adjustments in a previous study. ${ }^{11}$ It was a limitation that, besides mortality, the data did not permit us to analyze other functional outcomes because we registered no other outcomes.

We report a significant reduction in acute hospital stays, partly because some of the mild strokes were managed in outpatient clinics. The reorganization has hence likely meant cost savings ${ }^{21}$ because shorter acute hospital stays for stroke patients result in lower hospital costs overall ${ }^{32}$ and because the outpatient setup is probably more costeffective. ${ }^{33}$ The results of this centralization are therefore unlikely to have been confounded by financial investment, as may have been the case with the reorganization of stroke services in London. ${ }^{20}$ Nevertheless, because the total hospital stay remained unchanged, we observed an increase in the nonacute hospital stay, including rehabilitation. The explanation for this finding is not clear. A significantly increased use of days for rehabilitation could be an explanation, but delayed start of rehabilitation and waiting for rehabilitation or transfer to a nursing home due to bottleneck problems may also have played a role. A more specific cost-effectiveness analysis is needed to make final conclusions on any financial implications.

Before the reorganization, patients deemed eligible for thrombolysis were already taken directly to 1 of 2 designated acute stroke units offering revascularization therapy. A centralized model has previously shown to increase the likelihood of receiving thrombolysis. ${ }^{34}$ However, we saw a nonsignificant increase in the proportion of patients treated with thrombolysis. This development mirrored that seen in the rest of the country even though the proportion of patients receiving thrombolysis was initially significantly higher in the CDR than in the rest of Denmark and hence less likely to increase further. We therefore speculate that this takes place because all patients were preassessed and treated in a designated acute stroke unit regardless of whether they were found eligible for revascularization treatment. We also learned that the longer travel distances to a specialized stroke unit did not lead to fewer but actually more (nonsignificant) early stroke admissions (within 4.5 hours). We think specialized preassessment (telephone conferences 
Table 5 Eleven clinical guideline-recommended process performance measures of acute stroke care included in all-or-none

\begin{tabular}{|c|c|c|c|c|c|c|c|}
\hline \multirow{3}{*}{$\begin{array}{l}\text { Performance measures, } \\
\%(95 \% \mathrm{Cl}) \text {, cases } / \text { total }^{\mathrm{a}}\end{array}$} & \multicolumn{2}{|l|}{ CDR } & \multirow[b]{3}{*}{ RR $(95 \% \mathrm{Cl})$} & \multicolumn{2}{|l|}{ Rest of Denmark } & \multirow[b]{3}{*}{ RR $(95 \% \mathrm{Cl})$} & \multirow{3}{*}{$\begin{array}{l}\text { CDR/Rest of Denmark } \\
\text { Before/After } \\
\text { DID RR }(95 \% \mathrm{Cl})\end{array}$} \\
\hline & Before & After & & Before & After & & \\
\hline & & & & & & & \\
\hline \multicolumn{8}{|l|}{$\begin{array}{l}\text { Specialized } \\
\text { stroke unit } \leq 2 \mathrm{~d}\end{array}$} \\
\hline Unadjusted & $\begin{array}{l}90.3(89.1-91.5) \\
2,052 / 2,272\end{array}$ & $\begin{array}{l}92.4(91.4-93.5) \\
2,162 / 2,339\end{array}$ & $1.02(0.94-1.11)$ & $\begin{array}{l}94.2(93.7-94.7) \\
8,186 / 8,691\end{array}$ & $\begin{array}{l}94.7(0.94-0.95) \\
8,163 / 8,616\end{array}$ & $1.01(0.98-1.03)$ & $1.02(0.94-1.11)$ \\
\hline \multicolumn{8}{|l|}{$\begin{array}{l}\text { Antiplatelet } \\
\text { therapy } \leq 2 \mathrm{~d}\end{array}$} \\
\hline Unadjusted & $\begin{array}{l}93.5(92.2-94.8) \\
1,350 / 1,444\end{array}$ & $\begin{array}{l}95.4(94.3-96.4) \\
1,480 / 1,552\end{array}$ & $1.02(0.98-1.06)$ & $\begin{array}{l}93.7(93.0-94.3) \\
5,400 / 5,766\end{array}$ & $\begin{array}{l}93.6(93.0-94.3) \\
5,243 / 5,599\end{array}$ & $1.00(0.99-1.01)$ & $1.02(0.98-1.06)$ \\
\hline \multicolumn{8}{|l|}{$\begin{array}{l}\text { Brain imaging } \\
(\mathrm{CT} \text { or } \mathrm{MRI}) \leq 0 \mathrm{~d}\end{array}$} \\
\hline Unadjusted & $\begin{array}{l}88.7(87.4-90.0) \\
2,026 / 2,283\end{array}$ & $\begin{array}{l}90.5(89.3-91.7) \\
2,126 / 2,349\end{array}$ & $1.02(0.98-1.07)$ & $\begin{array}{l}85.6(84.9-86.3) \\
7,484 / 8,743\end{array}$ & $\begin{array}{l}88.7(88.0-89.3) \\
7,663 / 8,641\end{array}$ & $1.04(1.01-1.06)$ & $0.98(0.94-1.03)$ \\
\hline \multicolumn{8}{|l|}{$\begin{array}{l}\text { Physiotherapy } \\
\text { (assessment) } \leq 2 \mathrm{~d}\end{array}$} \\
\hline Unadjusted & $\begin{array}{l}86.8(85.3-88.3) \\
1,706 / 1,966\end{array}$ & $\begin{array}{l}92.6(91.4-93.8) \\
1,746 / 1,886\end{array}$ & $1.07(1.03-1.10)$ & $\begin{array}{l}86.4(85.6-87.2) \\
5,946 / 6,884\end{array}$ & $\begin{array}{l}91.2(90.5-91.9) \\
5,958 / 6,533\end{array}$ & $1.06(1.02-1.10)$ & $1.01(0.96-1.06)$ \\
\hline \multicolumn{8}{|l|}{$\begin{array}{l}\text { Occupational therapist } \\
\text { (assessment) } \leq 2 \mathrm{~d}\end{array}$} \\
\hline Unadjusted & $\begin{array}{l}86.6(85.1-88.1) \\
1,691 / 1,953\end{array}$ & $\begin{array}{l}93.4(92.3-94.5) \\
1,766 / 1,891\end{array}$ & $1.08(1.05-1.10)$ & $\begin{array}{l}83.6(82.8-84.5) \\
5,843 / 6,986\end{array}$ & $\begin{array}{l}89.8(89.1-90.5) \\
5,931 / 6,606\end{array}$ & $1.07(1.03-1.12)$ & $1.00(0.96-1.05)$ \\
\hline \multicolumn{8}{|l|}{ Mobilization $\leq 0 \mathrm{~d}$} \\
\hline Unadjusted & $\begin{array}{l}79.1(77.2-81.0) \\
1,396 / 1,764\end{array}$ & $\begin{array}{l}89.5(88.1-90.9) \\
1,655 / 1,849\end{array}$ & $1.13(1.00-1.28)$ & $\begin{array}{l}75.1(74.0-76.2) \\
4,777 / 6,361\end{array}$ & $\begin{array}{l}85.1(84.2-85.9) \\
5,289 / 6,218\end{array}$ & $1.13(1.06-1.20)$ & $1.00(0.87-1.14)$ \\
\hline \multicolumn{8}{|l|}{$\begin{array}{l}\text { Nutrition } \\
\text { (assessment) } \leq 2 \mathrm{~d}\end{array}$} \\
\hline Unadjusted & $\begin{array}{l}86.4(84.9-87.8) \\
1,841 / 2,132\end{array}$ & $\begin{array}{l}85.7(84.2-87.1) \\
1,888 / 2,204\end{array}$ & $0.99(0.92-1.07)$ & $\begin{array}{l}84.8(84.0-85.6) \\
6,101 / 7,194\end{array}$ & $\begin{array}{l}87.1(86.3-87.9) \\
6,376 / 7,320\end{array}$ & $1.03(0.98-1.07)$ & $0.97(0.89-1.05)$ \\
\hline \multicolumn{8}{|l|}{ Indirect swallow test $\leq 2 \mathrm{~d}$} \\
\hline Unadjusted & $\begin{array}{l}82.7(81.1-84.3) \\
1,727 / 2,088\end{array}$ & $\begin{array}{l}84.8(83.3-86.3) \\
1,841 / 2,171\end{array}$ & $1.03(0.96-1.09)$ & $\begin{array}{l}81.6(80.7-82.5) \\
5,912 / 7,242\end{array}$ & $\begin{array}{l}85.5(84.7-86.3) \\
6,459 / 7,553\end{array}$ & $1.05(1.01-1.09)$ & $0.98(0.91-1.05)$ \\
\hline
\end{tabular}

Direct swallow test $\leq 2 \mathrm{~d}$ 
between general practitioners or paramedics and stroke specialists in all cases of stroke suspicion) may have created a higher awareness of the urgency of stroke.

It is a limitation that the patients admitted to same-day treatment at outpatient clinics, which is likely the most costeffective setup, ${ }^{33}$ could not be distinguished from hospitalized patients admitted for $<24$ hours. We therefore cannot describe the outcomes of these 2 groups.

There are no data on patients with TIA treated in the outpatient clinics in the study periods. Therefore, the effects of centralizing the TIA service in the CDR remain unknown.

We could not include patients with missing information on stroke severity in the multivariable models. However, because the prevalence of missing information was low $(2 \%-7 \%)$, this is unlikely to have affected the results.

In this study, we used all stroke events from the rest of Denmark to account for general stroke care trends. Other parts of Denmark may also have reorganized their stroke treatment in this period. Collectively, this may have diluted the effect described here. One other region initiated a stepwise centralization model, but because only parts of this region were centralized in the "after" period, this region was included in the control group. However, a sensitivity analysis excluding this region from the data did not change the overall results.

Before the reorganization, some process indicators were significantly better in the CDR than in the rest of Denmark. Because there is a ceiling effect for most of the parameters analyzed, the DID may not fully illuminate the effects of reorganization for these measures.

Overall, the results showed significant effects from centralizing the stroke services in the CDR. We were able to organize the stroke services in a way likely to be more cost-effective while simultaneously maintaining or even improving highquality care and overall safety for stroke patients from an entire region using specialized acute stroke units only. The improvements we detected were comparable to the general trend in Denmark during the period. The aim of reorganizing stroke care was to reduce costs by reducing the acute length of stay for stroke, managing some of the minor strokes in outpatient clinics, and drawing on early discharge home team care. These goals were met. Nevertheless, to make final conclusions on the financial implications, a more specific costeffective analysis is needed.

\section{Author contributions}

S.H., S.P.J., D.D., and G.A. designed the study. S.H. and S.P.J. obtained approvals from the Danish Data Protection Agency and the Danish clinical registries. S.H., S.P.J., T.T., and H.H.H. handled the data management and statistical analysis. S.H. drafted the initial manuscript. S.H., P.v.W.-M., C.Z.S., 
Table 6 Differences in hospital readmissions and mortality rates in the CDR compared with the rest of Denmark after centralization of acute stroke services

CDR

Before

After

9.1 (7.9-10.3)

$209 / 2,290$

$10.2(9.0-11.4)$

$240 / 2,355$

$1.10(0.92-1.31)$

$.18(1.02-1.35)$

$10.2(9.6-10.86)$

$900 / 8,802$

$10.8(10.2-11.5)$

$941 / 8,694$

After

Before

After

(2)

Adjusted $^{\mathrm{a}}$

30.9 (29.0-32.8)

$707 / 2,290$

$31.2(29.3-33.1)$
$735 / 2,355$

$0.99(0.92-1.07)$

$1.04(1.00-1.08)$

32.6 (31.6-33.6)

$2,867 / 8,802$

32.4 (31.4-33.4) $2,817 / 8,694$

Adjusted $^{\mathrm{a}}$

$1.04(1.00-1.08)$

Mortality, \% (95\% Cl), cases/total

Mortality at $30 \mathrm{~d}$ (all stroke types)

Unadjusted

d

Adjusted

Mortality at $30 \mathrm{~d}$ (ischemic stroke) ${ }^{\mathrm{b}}$

\begin{tabular}{l}
\hline Unadjusted \\
\hline Adjusted $^{\mathrm{c}}$ \\
\hline $\begin{array}{c}\text { Mortality at } 30 \mathrm{~d} \text { (intracerebral } \\
\text { hemorrhage) }\end{array}$ \\
\hline
\end{tabular}

Unadjusted

$27.6(22.7-32.6)$
$87 / 315$

$24.7(19.7-29.8)$

$24.7(19.7-$
$70 / 283$

$5.9(4.9-7.0)$
$123 / 2,072$

$7.6(6.4-8.8)$
$150 / 1,975$

$123 / 2,072$

$8.2(7.1-9.3)$

$193 / 2,355$

$0.76(0.62-0.94)$

$0.99(0.76-1.29)$

$10.8(10.2-11.5)$

$953 / 8,802$

$10.0(9.4-10.6)$

$868 / 8,694$

CDR/Rest of Denmark

Before/After

$\mathrm{HR}(95 \% \mathrm{Cl})$

DID HR $(95 \% \mathrm{CI})$

$0.76(0.62-0.94)$

27

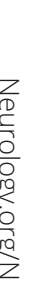


N.H., A.T.M, T.H., M.S.P., N.R.d.M.A., D.D., and G.A. contributed to data collection. All authors made substantial contributions to the study design and interpretation of the findings, contributed to the drafting of the article or to critical revision of important intellectual content, gave final approval of the version to be published, and agreed to be accountable for all aspects of the work in ensuring that questions related to the accuracy or integrity of any part of the article are appropriately investigated and resolved. G.A. is the guarantor.

\section{Study funding}

This study was supported by the University of Aarhus, Denmark; the Lundbeck Foundation, Denmark; and the Laerdal Foundation, Norway.

\section{Disclosure}

S. Hastrup has served on the scientific advisory boards for AstraZeneca. She has received research grants from University of Aarhus and Lundbeck Foundation. S. Johnsen has received a research grant from Pfizer and has served as advisory board member for Pfizer, Bristol-Myer Squibb, and Bayer. He has also served as a speaker for Pfizer, Bristol-Myer Squibb, Bayer, Boehringer-Ingelheim, and St. Jude. He has received research grants from the Danish Research Council and TrygFonden. T. Terkelsen and H.H. Hundborg report no disclosures relevant to the manuscript. P. von Weitzel-Mudersbach received travel grants from Boehringer-Ingelheim and Bristol-Myer Squibb, and speaker honoraria from Bristol-Myer Squibb and Pfizer. C. Simonsen has received speaker honoraria from Bayer and Boehringer-Ingelheim. N. Hjort received travel funding from Bristol-Myer Squibb. A. Møller, T. Harbo, M. Poulsen, and N. Ruiz de Morales Ayudarte report no disclosures relevant to the manuscript. D. Damgaard received honoraria from serving on the scientific advisory board of Amgen Pharmaceuticals; received funding for 2 trips from Bayer Pharmaceuticals and 1 trip from Bristol-Myer Squibb Pharmaceuticals; received speaker honoraria from Bayer Pharmaceuticals, Boehringer-Ingelheim Pharmaceuticals, Bristol-Myer Squibb Pharmaceuticals, and Pfizer Pharmaceuticals; and served as primary investigator for a clinical trial sponsored by Boehringer-Ingelheim Pharmaceuticals and for a clinical trial sponsored by Bayer Pharmaceuticals. G. Andersen received speaker honorarium from Medtronic and research grants from TrygFonden, NovoNordisk Foundation, and Lundbeck Foundation. Go to Neurology.org/N for full disclosures.

Received November 28, 2017. Accepted in final form April 13, 2018.

\section{References}

1. Feigin VL, Forouzanfar MH, Krishnamurthi R, et al. Global and regional burden of stroke during 1990-2010: findings from the Global Burden of Disease Study 2010. Lancet 2014;383:245-254.

2. Katzan IL, Spertus J, Bettger JP, et al. Risk adjustment of ischemic stroke outcomes for comparing hospital performance: a statement for healthcare professionals from the American Heart Association/American Stroke Association. Stroke 2014;45:918-944.

3. Bray BD, Ayis S, Campbell J, et al. Associations between the organisation of stroke services, process of care, and mortality in England: prospective cohort study. BMJ 2013;346:£2827. 
4. Ingeman A, Andersen G, Hundborg HH, Svendsen ML, Johnsen SP. In-hospital medical complications, length of stay, and mortality among stroke unit patients. Stroke 2011;42:3214-3218.

5. Stroke Unit Trialists' Collaboration. Organised inpatient (stroke unit) care for stroke. Cochrane Database Syst Rev 2013:CD000197.

6. Langhorne P, Fearon P, Ronning OM, et al. Stroke unit care benefits patients with intracerebral hemorrhage: systematic review and meta-analysis. Stroke 2013;44: 3044-3049.

7. Lin HC, Xirasagar S, Chen CH, Lin CC, Lee HC. Association between physician volume and hospitalization costs for patients with stroke in Taiwan: a nationwide population-based study. Stroke 2007;38:1565-1569.

8. Saposnik G, Baibergenova A, O’Donnell M, et al. Hospital volume and stroke outcome: does it matter? Neurology 2007;69:1142-1151.

9. Svendsen ML, Ehlers LH, Ingeman A, Johnsen SP. Higher stroke unit volume associated with improved quality of early stroke care and reduced length of stay. Stroke 2012;43:3041-3045.

10. Tsugawa Y, Kumamaru H, Yasunaga H, Hashimoto H, Horiguchi H, Ayanian JZ. The association of hospital volume with mortality and costs of care for stroke in Japan. Med Care 2013;51:782-788.

11. Morris S, Hunter RM, Ramsay AI, et al. Impact of centralising acute stroke services in English metropolitan areas on mortality and length of hospital stay: difference-indifferences analysis. BMJ 2014;349:g4757.

12. Ramsay AI, Morris S, Hoffman A, et al. Effects of centralizing acute stroke services on stroke care provision in two large metropolitan areas in England. Stroke 2015;46: 2244-2251.

13. Smith EE, Shoba N, Dai D, et al. Risk score for in-hospital ischemic stroke mortality derived and validated within the Get With The Guidelines-Stroke program. Circulation 2010;122:1496-1504.

14. Campbell BC, Meretoja A, Donnan GA, Davis SM. Twenty-year history of the evolution of stroke thrombolysis with intravenous alteplase to reduce long-term disability. Stroke 2015;46:2341-2346.

15. Hacke W, Kaste M, Fieschi C, et al. Intravenous thrombolysis with recombinant tissue plasminogen activator for acute hemispheric stroke: the European Cooperative Acute Stroke Study (ECASS). JAMA 1995;274:1017-1025.

16. Saver JL, Fonarow GC, Smith EE, et al. Time to treatment with intravenous tissue plasminogen activator and outcome from acute ischemic stroke. JAMA 2013;309:2480-2488.

17. Schmitz ML, Simonsen CZ, Hundborg H, et al. Acute ischemic stroke and long-term outcome after thrombolysis: nationwide propensity score-matched follow-up study. Stroke 2014;45:3070-3072.

18. Zhong W, Geng N, Wang P, Li Z, Cao L. Prevalence, causes and risk factors of hospital readmissions after acute stroke and transient ischemic attack: a systematic review and meta-analysis. Neurol Sci 2016;37:1195-1202.
19. Oliver D. Readmission rates reflect how well whole health and social care systems function. BMJ 2014;348:g1150.

20. Hill AM. Centralising acute stroke services: study confounded by financial investment. BMJ 2014;349:g5710.

21. Douw K, Nielsen CP, Pedersen CR. Centralising acute stroke care and moving care to the community in a Danish health region: challenges in implementing a stroke care reform. Health Policy 2015;119:1005-1010.

22. Mainz J, Krog BR, Bjornshave B, Bartels P. Nationwide continuous quality improvement using clinical indicators: the Danish National Indicator Project. Int J Qual Health Care 2004;16(suppl 1):i45-i50.

23. Thorvaldsen P, Davidsen M, Bronnum-Hansen H, Schroll M. Stable stroke occurrence despite incidence reduction in an aging population: stroke trends in the Danish Monitoring Trends and Determinants in Cardiovascular Disease (MONICA) population. Stroke 1999;30:2529-2534.

24. Wildenschild C, Mehnert F, Thomsen RW, et al. Registration of acute stroke: validity in the Danish Stroke Registry and the Danish National Registry of Patients. Clin Epidemiol 2013;6:27-36.

25. Schmidt M, Schmidt SA, Sandegaard JL, Ehrenstein V, Pedersen L, Sorensen HT. The Danish National Patient Registry: a review of content, data quality, and research potential. Clin Epidemiol 2015;7:449-490.

26. Pedersen CB, Gotzsche H, Moller JO, Mortensen PB. The Danish Civil Registration System: a cohort of eight million persons. Dan Med Bull 2006;53:441-449.

27. Thorvaldsen P, Kuulasmaa K, Rajakangas AM, Rastenyte D, Sarti C, Wilhelmsen L. Stroke trends in the WHO MONICA project. Stroke 1997;28:500-506.

28. Feigin VL, Forouzanfar MH, Krishnamurthi R, et al. Global and regional burden of stroke during 1990-2010: findings from the Global Burden of Disease Study 2010. Lancet 2014;383:245-254.

29. Thrift AG, Thayabaranathan T, Howard G, et al. Global stroke statistics. Int J Stroke 2017;12:13-32.

30. Truelsen T, Piechowski-Jozwiak B, Bonita R, Mathers C, Bogousslavsky J, Boysen G. Stroke incidence and prevalence in Europe: a review of available data. Eur J Neurol 2006; 13:581-598.

31. Henriksen DP, Rasmussen L, Hansen MR, Hallas J, Pottegard A. Comparison of the five Danish regions regarding demographic characteristics, healthcare utilization, and medication use: a descriptive cross-sectional study. PLoS One 2015;10:e0140197.

32. Huang YC, Hu CJ, Lee TH, et al. The impact factors on the cost and length of stay among acute ischemic stroke. J Stroke Cerebrovasc Dis 2013;22:e152-e158.

33. O'Brien E, Priglinger ML, Bertmar C, et al. Rapid access point of care clinic for transient ischemic attacks and minor strokes. J Clin Neurosci 2016;23:106-110.

34. Lahr MM, Luijckx GJ, Vroomen PC, van der Zee DJ, Buskens E. Proportion of patients treated with thrombolysis in a centralized versus a decentralized acute stroke care setting. Stroke 2012;43:1336-1340. 


\section{Neurology}

\section{Effects of centralizing acute stroke services: A prospective cohort study \\ Sidsel Hastrup, Soren P. Johnsen, Thorkild Terkelsen, et al. \\ Neurology 2018;91;e236-e248 Published Online before print June 15, 2018 \\ DOI 10.1212/WNL.0000000000005822}

\section{This information is current as of June 15, 2018}

\section{Updated Information \& Services}

References

Citations

Subspecialty Collections

\section{Permissions \& Licensing}

Reprints including high resolution figures, can be found at: http://n.neurology.org/content/91/3/e236.full

This article cites 33 articles, 17 of which you can access for free at: http://n.neurology.org/content/91/3/e236.full\#ref-list-1

This article has been cited by 3 HighWire-hosted articles: http://n.neurology.org/content/91/3/e236.full\#\#otherarticles

This article, along with others on similar topics, appears in the following collection(s):

\section{All Cerebrovascular disease/Stroke}

http://n.neurology.org/cgi/collection/all_cerebrovascular_disease_strok e

All Health Services Research

http://n.neurology.org/cgi/collection/all_health_services_research

Outcome research

http://n.neurology.org/cgi/collection/outcome_research

Patient safety

http://n.neurology.org/cgi/collection/patient_safety

Information about reproducing this article in parts (figures,tables) or in its entirety can be found online at:

http://www.neurology.org/about/about_the_journal\#permissions

Information about ordering reprints can be found online:

http://n.neurology.org/subscribers/advertise

Neurology ${ }^{\circledR}$ is the official journal of the American Academy of Neurology. Published continuously since 1951, it is now a weekly with 48 issues per year. Copyright (C 2018 The Author(s). Published by Wolters Kluwer Health, Inc. on behalf of the American Academy of Neurology.. All rights reserved. Print ISSN: 0028-3878. Online ISSN: 1526-632X.

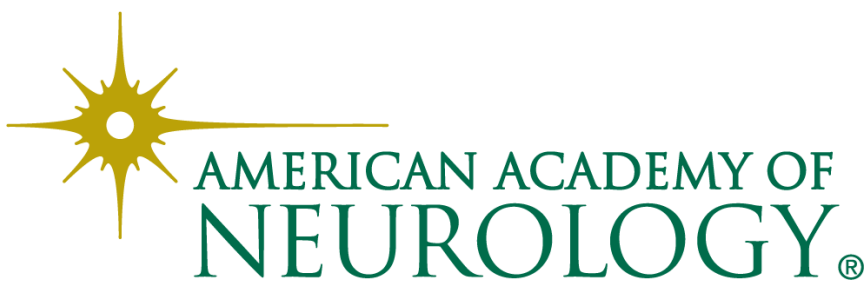

